\title{
IMPLEMENTASI PENDIDIKAN KARAKTER DI SD NEGERI SIDOMULYO 04 KECAMATAN UNGARAN TIMUR KABUPATEN SEMARANG
}

\author{
Nani Mediatati \\ nani.mediatati@staff.uksw.edu \\ Program Studi S1 PPKn \\ FKIP - Universitas Kristen Satya Wacana
}

\begin{abstract}
ABSTRAK
Penelitian ini bertujuan untuk mendiskripsikan implementasi pendidikan karakter di SD Negeri Sidomulyo 04 Kecamatan Ungaran Timur Kabupaten Semarang tahun pelajaran 2010/2011. Jenis penelitian ini adalah penelitian diskriptif. Subyek penelitiannya adalah Kepala Sekolah, guru kelas 1 sampai kelas 6, dan siswa kelas 6 yang diambil sampel sebanyak 15 siswa. Teknik pengumpulan data melalui wawancara, observasi, dan dokumentasi. Teknik analisis data menggunakan teknik analisis deskriptif kualitatif. Hasil penelitian menunjukkan bahwa SD Negeri Sidomulyo 04 Kecamatan Ungaran Timur Kabupaten Semarang telah mengimplementasikan pendidikan karakter sejak tahun pelajaran 2004. Pendidikan karakter diimplementasikan melalui kegiatan intrakurikuler, ekstrakurikuler, dan pembiasaan diri. Melalui kegiatan intrakurikuler, pendidikan karakter dilaksanakan dalam pembelajaran setiap mata pelajaran, mulai dari penyusunan rencana pelaksanaan pembelajaran (RPP), pelaksanaan pembelajaran di kelas, dan evaluasi. Dalam kegiatan ekstrakurikuler, pendidikan karakter dilaksanakan melalui kegiatan kepramukaan; seni, budaya dan ketrampilan; keagamaan; olah raga; pengembangan IPTEK; dan pelayanan konseling. Selanjutnya pendidikan karakter dilakukan melalui pembiasaan diri yaitu berjabat tangan dan memberi salam setiap pagi baik kepala sekolah, guru, karyawan, dan siswa; mendengarkan lagu nasional, daerah, rohani yang diputar dari kantor setiap pagi sebelum masuk kelas dan mulai pelajaran; menyisihkan sebagian uang saku sebagai bentuk kepedulian sosial dan sikap berbagi; kerja bakti bersama; dan makan bersama. Guru dan kepala sekolah sangat berperan dalam pelaksanaan pendidikan karakter tersebut dan siswa memberi respon positif terhadap pelaksanaan pendidikan karakter di sekolah tersebut.
\end{abstract}

Kata Kunci: Implementasi, Pendidikan karakter

\section{PENDAHULUAN}

Pendidikan karakter merupakan salah satu tujuan pendidikan nasional sebagaimana dinyatakan dalam Pasal 1 UU SISDIKNAS tahun 2003 yaitu mengembangkan potensi peserta didik untuk memiliki kecerdasan, kepribadian dan akhlak mulia. Dengan demikian tujuan pendidikan nasional tidak hanya membentuk manusia
Indonesia yang cerdas tapi juga berkepribadian atau berkarakter sehingga lahir generasi berkarakter yang menghormati nilai-nilai luhur bangsa dan agama. Pondasi bangsa yang kokoh diharapkan dapat dibangun dengan bangkitnya kesadaran bangsa melalui pendidikan karakter. Pendidikan karakter menjadi semakin mendesak untuk diterapkan dalam lembaga 
pendidikan mengingat berbagai macam perilaku non-edukatif kini telah merambah dalam lembaga pendidikan. Perilaku tersebut antara lain: fenomena kekerasan, pelecehan seksual, bisnis mania lewat sekolah, korupsi dan kesewenang-wenangan yang terjadi di kalangan sekolah (Doni Koesoema A., 2010: 115).

Banyak penelitian yang membuktikan bahwa karakter dapat mempengaruhi kesuksesan seseorang. Di antaranya, hasil penelitian di Harvard University, Amerika Serikat, yang menyatakan bahwa ternyata kesuksesan seseorang tidak ditentukan sematamata oleh pengetahuan dan kemampuan teknis (hard skill), tetapi oleh kemampuan mengolah diri dan orang lain (soft skill). Penelitian ini mengungkapkan bahwa kesuksesan hanya ditentukan sekitar 20\% oleh hard skill, dan sisanya (80\%) oleh soft skill. Bahkan, orang-orang tersukses didunia bisa berhasil dikarenakan lebih banyak didukung oleh kemampuan soft skill dari pada hard skill. Hal ini mengisyaratkan bahwa mutu pendidikan karakter peserta didik sangat penting untuk ditingkatkan. (Jamal Ma'mur A, 2011: 47).

Pendidikan karakter penting untuk diterapkan dalam diri peserta didik sedini mungkin dan secara berkelanjutan. Pendidikan karakter harus diterapkan pada semua jenjang pendidikan, namun porsi yang lebih besar harus diberikan pada jenjang SD dibandingkan dengan jenjang pendidikan lainnya. Hal itu karena siswa SD masih belum terkontaminasi oleh sifat-sifat yang kurang baik sehingga sangat memungkinkan untuk ditanamkan budi pekerti atau karakter luhur bangsa yang pada akhirnya melekat dijiwa anak-anak hingga nanti mereka dewasa. Pendidikan sekolah dasar strategis untuk pendidikan karakter, namun pada kenyataanya sistem pendidikan dini yang ada sekarang ini terlalu berorientasi pada pengembangan kognitif dan kurang memperhatikan perkembangan afektif, empati, dan rasa peserta didik.

Mulai tahun 2004 kurikulum sekolah menggunakan Kurikulum Berbasis Kompetensi (KBK) dan pada tahun 2006 berubah menjadi Kurikulum Tingkat Satuan Pendidikan (KTSP). Baik dalam Kurikulum Berbasis Kompetensi (KBK) maupun Kurikulum Tingkat Satuan Pendidikan (KTSP) ini pembelajaran setiap mata pelajaran dituntut untuk menampilkan realita keseharian yang dialami oleh siswa dan sekolah sebagai lembaga pendidikan diberi wewenang untuk menentukan prioritas pendidikan karakter dengan mempertimbangkan kompetensi siswa baik dalam bidang pengetahuan maupun yang berhubungan dengan pembiasaan diri (Megawangi, 2004:23).

SD Negeri Sidomulyo 04 Kecamatan Ungaran Timur Kabupaten Semarang merupakan salah satu sekolah yang telah mengimplementasikan pendidikan karakter (pendidikan berorientasi ketrampilan hidup) sejak tahun pelajaran 2004. Oleh karena itu layak untuk diteliti bagaimanakah implementasi pendidikan karakter di sekolah tersebut, bagaimana peran guru dan kepala sekolah serta tanggapan/respon siswa terhadap implementasi pendidikan karakter tersebut.

\section{TINJAUAN PUSTAKA}

\section{Pendidikan Karakter}

Istilah karakter secara harafiah berasal dari bahasa Latin "Charakter", yang berarti: watak, tabiat, sifat-sifat kejiwaan, budi pekerti, kepribadian atau akhlak. Istilah karakter dapat diartikan sebagai sifat 
kejiwaan, akhlak atau budi pekerti yang menjadi ciri khas seseorang atau sekelompok orang (Abdul Majid, Dian Andayani, 2010:119). Karakter juga bisa diartikan sikap, tabiat, akhlak, kepribadian yang stabil sebagai hasil proses konsolidasi secara progresif dan dinamis (Yahya Khan,2010:1). Ki Hadjar Dewantara memandang karakter sebagai watak atau budi pekerti. Menurutnya budi pekerti adalah bersatunya antara gerak fikiran, perasaan, dan kehendak atau kemauan yang kemudian menimbulkan tenaga.

Thomas Lickona $(1992,12)$ mendefinisikan pendidikan karakter sebagai upaya yang sungguh-sungguh untuk membantu seseorang memahami, peduli dan bertindak dengan landasan nilai-nilai etis. Pendidikan karakter mengandung tiga unsur pokok, yaitu mengetahui kebaikan (knowing the good), mencintai kebaikan (desiring the good), dan melakukan kebaikan (doing the good). Oleh karena itu orang yang berkarakter diartikan sebagai sifat alami seseorang dalam merespons situasi secara bermoral yang dimanifestasikan dalam tindakan nyata melalui tingkah laku yang baik, jujur, bertanggung jawab, menghormati orang lain dan karakter mulia lainnya. Nurul Zuriah (2002:19) memaparkan bahwa pendidikan karakter atau pendidikan budi pekerti merupakan program pengajaran di sekolah yang bertujuan mengembangkan watak atau tabiat siswa dengan cara menghayati nilai-nilai dan keyakinan masyarakat sebagai kekuatan moral dalam hidupnya melalui kejujuran, dapat dipercaya, disiplin, dan kerja sama yang menekankan ranah afektif (perasaan dan sikap) tanpa meninggalkan ranah kognitif (berfikir rasional) dan ranah psikomotorik (ketrampilan, trampil mengolah data, mengemukakan pendapat, dan kerjasama). Melalui pendidikan karakter diharapkan peserta didik mampu secara mandiri meningkatkan dan menggunakan pengetahuannya, mengkaji dan menginternalisasi serta mempersonalisasi nilai-nilai karakter dan akhlak mulia sehingga terwujud dalam perilaku sehari-hari. Hal ini sesuai dengan tujuan pendidikan karakter yang diharapkan Kementerian Pendidikan Nasional (2010: 9) yaitu: (1) mengembangkan potensi kalbu/nurani/afektif peserta didik sebagai manusia dan warganegara yang memiliki nilai-nilai budaya dan karakter bangsa; (2) mengembangkan kebiasaan dan perilaku peserta didik yang terpuji dan sejalan dengan nilai-nilai universal dan tradisi budaya bangsa yang religius; (3) menanamkan jiwa kepemimpinan dan tanggung jawab peserta didik sebagai generasi penerus bangsa; (4) mengembangkan kemampuan peserta didik menjadi manusia yang mandiri, kreatif, berwawasan kebangsaan; dan (5) mengembangkan lingkungan kehidupan sekolah sebagai lingkungan belajar yang aman, jujur, penuh kreativitas dan persahabatan, serta dengan rasa kebangsaan yang tinggi dan penuh kekuatan (dignity).

Karakter yang berkualitas perlu dibentuk dan dibina sejak usia dini. Usia dini, khususnya usia SD merupakan masa kritis bagi pembentukan karakter seseorang, penanaman moral melalui pendidikan karakter sedini mungkin kepada anak-anak adalah kunci utama membangun bangsa. Anak SD masih dalam tahap perkembangan operasional konkret. Tahap dimana mulai berkembangnya kecerdasan mereka untuk berpikir logis dan sistematis. Sehingga pendidikan karakter pada anak SD menjadi kunci dalam perubahan generasi muda yang lebih baik. Nilai-nilai budi pekerti dan karak- 
ter harus diajarkan oleh para guru disekolah dasar secara baik dan benar, agar nantinya anak-anak SD bisa memiliki jiwa dan kepribadian yang unggul. Jika anak-anak SD memiliki karakter yang baik, maka besar kemungkinan Indonesia akan memiliki generasi muda yang unggul dan bermartabat nantinya. Jadi pendidikan karakter di sekolah dasar menjadi faktor utama untuk membangun karakter generasi muda menjadi lebih baik.

\section{Peran Guru dan Kepala Sekolah dalam Pelaksanaan Pendidikan Karakter di Sekolah}

Dalam pengembangan karakter peserta didik di sekolah, guru memiliki posisi yang strategis sebagai pelaku utama. Guru merupakan sosok yang bisa ditiru atau menjadi idola bagi peserta didik. Guru bisa menjadi sumber inpirasi dan motivasi peserta didiknya. Sikap dan prilaku seorang guru sangat membekas dalam diri peserta didik, sehingga ucapan, karakter dan kepribadian guru menjadi cermin peserta didik. Dengan demikian guru memiliki tanggung jawab besar dalam menghasilkan generasi yang berkarakter, berbudaya, dan bermoral.

Ada beberapa strategi yang dapat memberikan peluang dan kesempatan bagi guru untuk memainkan peranannya secara optimal dalam hal pengembangan pendidikan karakter peserta didik di sekolah, diantaranya (1) optimalisasi peran guru dalam proses pembelajaran. Guru tidak seharusnya menempatkan diri sebagai aktor yang dilihat dan didengar oleh peserta didik, tetapi guru seyogyanya berperan sebagai sutradara yang mengarahkan, membimbing, memfasilitasi dalam proses pembelajaran, sehingga peserta didik dapat melakukan dan mene- mukan sendiri hasil belajarnya, (2) integrasi materi pendidikan karakter ke dalam mata pelajaran. Guru dituntut untuk perduli, mau dan mampu mengaitkan konsep-konsep pendidikan karakter pada materi-materi pembelajaran dalam mata pelajaran yang diampunya. Dalam hubungannya dengan ini, setiap guru dituntut untuk terus menambah wawasan ilmu pengetahuan yang berkaitan dengan pendidikan karakter, yang dapat diintergrasikan dalam proses pembelajaran, (3) mengoptimalkan kegiatan pembiasaan diri yang berwawasan pengembangan budi pekerti dan akhlak mulia. Para guru (pembina program) melalui program pembiasaan diri lebih mengedepankan atau menekankan kepada kegiatan-kegiatan pengembangan budi pekerti dan akhlak mulia yang kontekstual, kegiatan yang menjurus pada pengembangan kemampuan afektif dan psikomotorik, (4) penciptaan lingkungan sekolah yang kondusif untuk tumbuh dan berkembangnya karakter peserta didik.

Lingkungan terbukti sangat berperan penting dalam pembentukan pribadi manusia (peserta didik), baik lingkungan fisik maupun lingkungan spiritual. Untuk itu sekolah dan guru perlu untuk menyiapkan fasilitasfasilitas dan melaksanakan berbagai jenis kegiatan yang mendukung kegiatan pengembangan pendidikan karakter peserta didik,(5) menjalin kerjasama dengan orang tua peserta didik dan masyarakat dalam pengembangan pendidikan karakter. Bentuk kerjasama yang bisa dilakukan adalah menempatkan orang tua peserta didik dan masyarakat sebagai fasilitator dan nara sumber dalam kegiatan-kegiatan pengembangan pendidikan karakter yang dilaksanakan di sekolah, (6) menjadi figur teladan bagi peserta didik. Penerimaan peserta didik 
terhadap materi pembelajaran yang diberikan oleh seorang guru, sedikit tidak akan bergantung kepada penerimaan pribadi peserta didik tersebut terhadap pribadi seorang guru. Ini suatu hal yang sangat manusiawi, dimana seseorang akan selalu berusaha untuk meniru, mencontoh apa yang disenangi dari model/figurnya tersebut. Momen seperti ini sebenarnya merupakan kesempatan bagi seorang guru, baik secara langsung maupun tidak langsung menanamkan nilai-nilai karakter dalam diri pribadi peserta didik. Dalam proses pembelajaran, intergrasi nilai-nilai karakter tidak hanya dapat diintegrasikan ke dalam subtansi atau materi pelajaran, tetapi juga pada prosesnya (Jalam Ma'mur A, 2011: 57).

Disamping guru, peran yang dimainkan kepala sekolah dalam pelaksanaan pendidikan karakter juga sangat menentukan, yaitu melakukan pembinaan secara terusmenerus dalam hal pemodelan (modeling), pengajaran (teaching), dan penguatan karakter (reinforcing) yang baik terhadap semua warga sekolah (guru, peserta didik, dan karyawan). Kepala sekolah harus menjadi teladan bagi guru, karyawan, peserta didik, dan bahkan orang tua/wali peserta didik. Secara teratur dan berkesinambungan kepala sekolah harus melakukan komunikasi dengan warga sekolah mengenai terwujudnya pendidikan karakter tersebut. Beberapa hal yang perlu diperhatikan kepala sekolah dalam mewujudkan pendidikan karakter adalah (a) Berjuang atau berusaha keras untuk memodelkan diri atau menjadi model bagi semua guru, karyawan, dan peserta didik, (b) Mendorong semua guru dan karyawan untuk menjadi model karakter yang baik bagi semua peserta didik, (c) Menyediakan waktu dalam siklus berkelanjutan, bagi guru untuk meren- canakan dan melaksanakan pengintegrasian nilai-nilai karakter tertentu ke dalam pokok bahasan masing-masing mata pelajaran, (d) Menyelenggarakan kegiatan-kegiatan tertentu yang mendukung pembudayaan dan penanaman karakter di lingkungan sekolah, seperti seminar, pentas seni, dan pemutaran film (Darmiyati Zuchdi, 2011: 148).

\section{METODE PENELITIAN}

Jenis penelitian ini adalah penelitian diskriptif, karena penelitian ini hanya mendiskripsikan keadaan obyek atau peristiwa tanpa suatu maksud untuk mengambil kesimpulan yang berlaku secara umum. Yang menjadi subyek penelitian adalah Kepala Sekolah, guru kelas 1 sampai kelas 6, dan siswa kelas 6 SD Negeri Sidomulyo 04 yang diambil sampel sebanyak 15 siswa. Teknik pengumpulan data yang digunakan adalah wawancara, observasi, dan dokumentasi. Sedangkan teknik analisis data menggunakan teknik analisis deskriptif kualitatif

\section{HASIL PENELITIANDANPEMBAHASAN}

SD Negeri Sidomulyo 04 Kecamatan Ungaran Timur Kabupaten Semarang telah melaksanakan pendidikan berorientasi ketrampilan hidup (karakter) sejak tahun 2004 melalui kegiatan intrakurikuler, kegiatan ekstrakurikuler (pengembangan diri), dan pembiasaan diri dengan tujuan melatih siswa supaya memiliki ketrampilan hidup serta budi pekerti yang baik.

Dalam kegiatan intrakurikuler pendidikan karakteritik diberikan melalui pembelajaran setiap mata pelajaran. Dalam pembelajaran setiap mata pelajaran guru memasukkan unsur nilai/karakter yang bertujuan untuk membawa siswa semakin mampu bersikap, bertindak dan menempat- 
kan diri sesuai dengan situasi dan kondisi yang ada (peka pada situasi yang terjadi). Sebagai contoh dalam pembelajaran IPA, sebelum pembelajaran dimulai setelah berdoa guru memberikan petuah ("ngiseni") tentang nilai-nilai hidup bermasyarakat, misalnya sopan santun berbicara, duduk, berjalan dll.

Selain itu jika ada kejadian/peristiwa yang terjadi di masyarakat misalnya bencana alam di daerah tertentu, siswa diajak bagaimana bersyukur dan ikut berbela rasa dengan yang terkena bencana. Setelah guru menanamkan nilai-nilai hidup bermasyarakat yang baik kepada siswa baru masuk ke pembahasan materi pelajaran. Begitu juga di akhir pelajaran siswa diajak untuk membuat refleksi atau bertanya dalam diri sendiri apa manfaat dari pelajaran yang baru saja dipelajari. Penanaman nilai-nilai atau pendidikan karakter yang dilakukan guru melalui kegiatan intrakurikuler ini harus dimasukkan dalam rencana pelaksanaan pembelajaran (RPP) yang disusun guru.

Dalam kegiatan ekstrakurikuler pendidikan karakter diberikan melalui pengembangan diri yang bertujuan memberikan kesempatan pada siswa untuk mengembangkan dan mengekspresikan diri sesuai kebutuhan, bakat, minat setiap siswa sesuai dengan kondisi sekolah. Kegiatan pengembangan diri dilakukan melalui pelayanan konseling yang berkenaan dengan masalah dan kehidupan sosial, belajar, dan pengembangan karier siswa; kegiatan kepramukaan; kegiatan seni, budaya dan ketrampilan; kegiatan keagamaan; kegiatan olah raga; dan kegiatan pengembangan IPTEK.

Pendidikan karakter yang dilakukan melalui pembiasaan diri berupa kebiasaan berjabat tangan dan memberi salam setiap pagi baik kepala sekolah, guru, karyawan, dan siswa. Kepala sekolah tidak segan-segan untuk datang ke sekolah lebih awal kemudian berdiri di tengah halaman menunggu kedatangan dari para guru, karyawan, dan siswa lalu memberi salam dan berjabat tangan. Kebiasaan berjabat tangan dan memberi salam dengan mengucapkan kata yang disepakati bersama yaitu selamat pagi (senin, rabu), good morning (selasa, kamis), assalamu"alaikum, berkat Tuhan, shalom (Jumat), sugeng enjang (Sabtu). Kebiasaan mendengarkan lagu nasional, daerah, rohani yang diputar dari kantor setiap pagi sebelum masuk kelas dan mulai pelajaran, antara lain Garuda Pancasila, Maju tak gentar, Mentokmentok, Gundul-gundul pacul, Syahadat, Tombo ati.

Kebiasaan menyisihkan sebagian uang saku yang dimiliki siswa sebagai bentuk kepedulian sosial dan sikap berbagi. Kegiatan ini dilakukan pada hari rabu dan jumat, dimana uang yang dikumpulkan pada hari rabu untuk sosial (misalnya bila ada siswa atau orang tua sakit, bencana alam), sedangkan uang yang dikumpulkan pada hari jumat untuk kegiatan rohani dan dana mushola. Disamping itu juga membiasakan siswa belajar kerja dengan kerja bakti bersama membersihkan kelas, halaman, kantor dan ruang guru, UKS, kamar mandi dll. Kebiasaan makan bersama yang dilaksanakan pada hari jumat pagi setelah semua siswa olahraga bersama. Menu yang dibawa oleh siswa ditentukan sekolah sehari sebelumnya, bila ada siswa yang kesulitan menyiapkan menu dapat bekerjasama dengan pedagang yang ada di sekitar sekolah sehingga siswa tinggal membawa nasi saja.

Pelaksanaan pendidikan karakter ini didukung oleh peran dan keteladanan Kepala sekolah dalam bentuk tiga hal yaitu 
mengingatkan dan menginformasikan, membina, dan mengubah. Mengingatkan dan menginformasikan disini tekanannya lebih pada apa yang telah diprogramkan dan dilaksanakan setiap harinya dalam bentuk kegiatan intrakurikuler, ekstrakurikuler (pengembangan diri) dan pembiasaan diri yang ada dalam kurikulum sekolah. Bagi Kepala sekolah perihal mengingatkan dan menginformasikan hal-hal baru yang berhubungan dengan apa yang telah menjadi kebiasaan di sekolah setiap harinya itu wajib dan harus, yang diwujudkan dalam perbuatan kongkrit antara lain datang ke sekolah lebih awal dan mendahului dalam menyapa dan memberi salam.

Membina, disini Kepala sekolah selalu membiasakan diri untuk memberi pembinaan kepada para guru, karyawan, dan siswa setiap pagi sebelum pelajaran dimulai. Guru dan karyawan sebelum mulai melaksanakan tugas dikumpulkan di kantor untuk doa bersama dan diberi pengarahan yang berhubungan dengan tugas yang akan dilaksanakan. Bila ada guru atau karyawan yang terlambat diingatkan dan ditegur secara bersama pada waktu semua guru berkumpul sebab kepala sekolah tidak mau hanya semata-mata mencari kesalahan, tetapi bertujuan demi kemajuan dan perkembangan bersama. Begitu juga dengan siswa yang terlambat, ditanya mengapa terlambat dan memberi jalan keluar supaya tidak datang terlambat lagi. Hal ini dilakukan dalam rangka menanamkan nilai/sikap kedisiplinan. Kepala sekolah juga selalu membiasakan diri secara bergilir masuk ke kelas-kelas walaupun hanya sebentar sekedar menengok, tersenyum dan menyapa. Mengubah, ini lebih pada mengubah pandangan guru, karyawan, dan siswa. Dengan kebiasaan "Salam, Sapa, Senyum" membawa pada suasana yang bersahabat dan damai. Pengalaman diberi salam, disapa dan diberi senyum akan membekas sampai kapanpun. Siswa yang diberi salam, disapa dan diberi senyuman akan merasa dihargai sehingga perasaan malu, takut, minder menjadi hilang. Disamping itu kepala sekolah selalu mengupayakan kerjasama dengan berbagai pihak dalam melaksanakan pendidikan karakter yaitu komite sekolah, orang tua siswa, lembaga pemerintah, pedagang/home industry di sekitar sekolah.

Pelaksanaan pendidikan karakter ini juga didukung oleh peran dan keteladanan guru karena apa yang dilakukan oleh guru akan ditiru oleh siswa. Keteladanan guru yang baik dapat membimbing siswa membentuk sikap atau pribadi yang baik. Seperti halnya yang dilakukan Kepala sekolah, para guru di SD Negeri Sidomulyo 04 juga tidak segan-segan untuk terlebih dahulu menyapa, memberi salam kepada Kepala sekolah, sesama guru, dan terlebih pada siswa. Guru tidak hanya menyuruh/memerintah tetapi juga ikut melakukan apa yang diperintahkan pada siswa. Bila guru melakukan suatu kesalahan guru juga berani untuk minta maaf terlebih dahulu kepada siswa.

Hasil dari pendidikan karakter yang selama ini dilakukan sekolah adalah terjadinya perubahan perilaku siswa menjadi lebih baik terutama sikap kepedulian siswa dalam bentuk saling menyapa, memberi salam, bertanya, menolong, berbagi, menjaga kebersihan dan keindahan sekolah, sikap hormat dan menghargai satu sama lain. Siswa pada awalnya dalam menerima pendidikan karakter ini merasa terpaksa dan ogah-ogahan, selain itu juga ada rasa malu, minder, dan takut. Namun semua rasa tersebut hilang berkat keramahan, keteladanan, kedekatan kepala sekolah dan guru dalam 
merengkuh siswa dengan salam, sapa, dan senyum. Siswa selalu diajak dan didorong untuk selalu berani, berani untuk bertanya, menyapa, menjawab dan mengutarakan pendapat, serta mengakui kebenaran yang ada (sikap mengampuni dan meminta maaf).

\section{KESIMPULAN}

Implementasi Pendidikan Karakter di SD Negeri Sidomulyo 04 Kecamatan Ungaran Timur Kabupaten Semarang dilakukan melalui kegiatan intrakurikuler, kegiatan ekstrakurikuler (pengembangan diri), dan pembiasaan diri. Peran dan keteladanan Kepala sekolah serta guru sangat menentukan keberhasilan implementasi pendidikan karakter tersebut.

\section{DAFTAR PUSTAKA}

Abdul majid, Dian andayani. 2010. Pedidikan karakter dalam perspektif Islam. Bandung: Insan Cita Utama.

Doni Koesoema A. 2010. Pendidikan Karakter Strategi Mendidik Anak di Zaman Global. Jakarta: Grasindo.
Darmiyati Zuchdi. 2011. Pendidikan Karakter dalam Perspektif Teori dan Praktik. rev.ed. Yogyakarta: UNY Press.

Jamal Ma'mur Asmani. 2011. Buku Panduan Internalisasi Pendidikan Karakter di Sekolah. Yogyakarta: Diva Press.

Kemendiknas. 2010. Pengembangan Pendidikan Budaya dan Karakter Bangsa, Pedoman Sekolah, Jakarta: Kemendiknas.

Nurul Zuriah. 2002. Pendidikan Moral dan Budi Pekerti. Bandung: PT Rosada Karya.

Ratna Megawangi. 2004. Pendidikan Karakter Solusi Yang Tepat Untuk Membangun Bangsa. Indonesia Heritage Foundation Jakarta.

Thomas Lickona. 1992. Educating For Character: How Our School Can Teach Respect and Responsibility. New York: Bantam Books.

Yahya Khan. 2010. Pendidikan Karakter Berbasis Potensi Diri: Mendongkrak Kualitas Pendidikan. Yogyakarta: Pelangi Publishing. 